Anasazi settlement took place in the Hohokam province. Timbers from the Mogollon houses have been dated, making correlation with Anasazi possible. It is suggested that basic Mogollon, not yet clearly defined, was contemporary with Modified Basket Maker, and its later stages of development with Developmental Pueblo, Great Pueblo, and Renaissance.

Investigation of the relations of the Mogollon culture to various phases of Anasazi, both Basket Maker and Pueblo, have been in progress through. out the summer of 1939: at Glenwood, New Mexico (Field Museum of Natural History, Chicago); a second expedition working also near Glenwood (Logan Museum) ; and on a village site occupied A.D. 700-800, south of Showlow, Arizona (Arizona State Museum).

'Smithsonian Inst. : Bur. Amer. Ethnol. Bull., 121 (1939).

\title{
OBITUARIES
}

\section{Prof. H. H. Meyer}

$\mathrm{T}$ HE death of Hans Horst Meyer on October 6 severs perhaps the last direct link with the beginnings of experimental pharmacology as a separate scienco.

Meyer was born on March 17, 1853, in Insterburg in Kast Prussia, and studied medicine at Konigsberg, Leipzig and Berlin. A story goes that he passed his qualifying examination in all subjects except pharmacology and that it was to rectify this defect that he undertook an investigation under Jaffo, which gave him an introduction to the technique and literature of experimental physiology. Later he went to Strassburg to work under Schmiedeberg, as did nearly all the prospective pharmacologists of the time, and had just been appointed assistant to Schmiedeberg when he was called to Dorpat in 1881. Here he succeeded Boehm, the immediate successor of Buchheim, who had established in Dorpat the first laboratory for experimental pharmacology. In 1884 he became professor at Marburg where he worked for twenty years, after which, in 1904, he became director of the Pharmacological Institute in Vienna. He held this appointment for another twenty years, retiring in 1924. Still active, he was put in charge of a department for standardization of drugs, an appointment to which there was no age-limit and accommodation for which was given in his old laboratory. Up to a year or two ago, he still held every month in his own house a discussion on some pharmacological problem, which all the workers in the Pharmacological Institute, including his successor Pick, attended, and I am informed by one of the staff that up to the end Meyer took a leading part in these discussions, with little impairment of his enthusiasm or of the constructive and critical acuity of his mind.

Like most of the pharmacologists of his time, Nleyer was no narrow specialist. His investigations ranged over a wide feld, and behind it all was the desire to link up pharmacology with general biology and pathology on one hand and the treatment of disease on the other, towards the establishment of a more rational therapy. His influence is to be measured not only by his achievement but also by the vision which prompted it and by his guiding example of the lines upon which pharmacological investigation could be profitably pursued. Among the pharmacological problems he investigated were the action of the alkaloids of jaborandi and corydalis, acute poisoning with phosphorus and with metals, especially iron and bismuth, and the action of purgatives and astringents. Ho also did somo pioneer work on the reaction of the blood, on heat-regulation and on the action of diuretics and, resulting perhaps from his early work on jaborandi, he was especially interested in the development of the knowledge of the autonomic nervous system.

Meyer's claim to a permanent place in the history of pharmacology will, however, probably rest upon his contributions to two problems which lay outside the range of routine descriptive pharmacology. The first of these was his theory of the action of narcotics; he sought to explain their action by their relatively greater solubility in lipoids than in water, which led to their accumulation in the cells of the central nervous system with a consequent suspension of nervous activity.

This theory, which was independently and almost simultaneously suggested by Overton, has required subsequent modification, but its importance lies in its being a pioneer attempt, based upon experimental evidence, to solve one of the fundamental problems of pharmacology - the chemical or physical basis for the site and quality of pharmacological action. The other problem to which he introduced new con. ceptions was the action of bacterial toxins. Especially will bo remembered his suggestion that tetanus toxin travels to the central nervous system by way of the motor nerves rather than by the blood stream. He also showed that antitoxins were the more effectivo the earlier they wero given, and were relatively inefficaceous once the toxin had combined with the tissues.

Apart from his own work, Meyer profoundly influenced, by his wide knowledge and imaginative power, those who went to work with him from different parts of the world. His scientific eminence was recognized by many universities and learned societies outside his own country. He was the senior surviving honorary fellow of the British Physiological Society and, with J. J. Abel, was the first honorary member of the British Pharmacological Society. 